IRSH 55 (2010), Supplement, pp. 51-77 doi:10.1017/S0020859010000490 (C) 2010 Internationaal Instituut voor Sociale Geschiedenis

\title{
The Mid-Atlantic Islands: A Theatre of Early Modern Ecocide?
}

\author{
S TEFAN HALiK OW S I S M T H \\ Department of History, Swansea University \\ E-mail: S.Halikowski-Smith@swansea.ac.uk
}

Summary: The Iberian rediscovery of the mid-Atlantic islands in the late Middle Ages was accompanied by all kinds of utopian projections. However, within a hundred years, both human and animal populations were made extinct, and the rich forest cover was rapidly depleted for cash-cropping industries, primarily sugar. Historians view the migration of the international sugar industry from the mid-Atlantic islands to Brazil as an example of expanding economies of scale, but contemporary accounts indicate what now might be called widespread ecocide as a major contributing factor. This essay looks at the environmental ramifications of the sugar industry as well as other cultures, and assesses whether it is indeed appropriate to speak of ecocide in the context of the mid-Atlantic islands in the early modern period.

The neologism "ecocide" can be used to refer to any large-scale destruction of the natural environment, though the context into which the term was born turned on the catastrophic consequences to the environment unleashed by the Vietnam War with its extensive use of napalm. ${ }^{I}$ While the war moved Jean-Paul Sartre famously to equate colonialism with genocide, commentators quickly extended his declaration to ecocide. ${ }^{2}$ Ecocide became a primary accusation in the ongoing political struggle of the native North American Indians against petrochemical companies since $1978 .{ }^{3}$

While a number of activists today like Patrick Hossay and Peter Ward ${ }^{4}$ more generally propound grim prognoses for the human species as

I. Barry Weisberg, Ecocide in Indochina: The Ecology of War (San Francisco, CA, I970).

2. Jean-Paul Sartre, "On Genocide”, Ramparts (February 1968).

3. Ward Churchill, Struggle for the Land: Native North American Resistance to Genocide, Ecocide and Colonialization (San Francisco, CA, 2002). See especially the chapter entitled "Last Stand at Lubicon Lake".

4. Patrick Hossay, "Ecocide" and "Toxic Planet", in idem, Unsustainable: A Primer for Global Environmental and Social Justice (London, 2006), pp. 22-34; Peter Ward, The Medea Hypothesis: Is Life on Earth Ultimately Self-Destructive? (Princeton, NJ, 2009). 
enshrined in the "Medea hypothesis", namely that we are on the path to self-destruction, there is room to discuss whether this is as a result of the "characteristics of evolution having as its basic unit the species rather than the biosphere", or if it was specifically the Industrial Revolution that conjured up new threats to the global environment. Here, early modern historians might try to make a case for ecocide occurring at an earlier date on the basis of the strong and sustained social protest that environmental damage provoked.' At any rate, Richard Grove is adamant that colonial ecological interventions, especially in deforestation, irrigation, and soil "protection", have exercised a far more profound influence over most people than the more conspicuous and dramatic political aspects of colonial rule that have traditionally preoccupied historians. ${ }^{6}$

Whilst critics of the belief in ecocide usually assert that human impacts are not sufficiently serious as to threaten the Earth's ability to support complex life, and underestimate Nature's capacity to adapt, further problems are created for the ecocide lobby by a necessary distinction between the "murder of the environment" and the "state of nature" itself displaying "universal signs of violence", as Darwin observed.

The case study for ecocide chosen here will employ the looser definition suggested above - any large-scale destruction of the natural environment - and apply it to the mid-Atlantic islands, sometimes referred to in the literature as Macronesia. This comprises the Canary Islands, "rediscovered" during fourteenth-century maritime voyages undertaken from Portugal, Genoa, and Majorca, as well as the uninhabited archipelago of Madeira discovered around I4I 8, the Azores around I432, and Cape Verde around I456. Collectively, this space has been christened the Méditerranée Atlantique by the Portuguese historian Luís Adão da Fonseca, and it emerged from the mists of history as part of the greatest triumph of the fifteenth century, the conquest of the Atlantic. ${ }^{7}$

The previously uninhabited islands of the Atlantic are often drawn attention to as primary examples of ecocide, both in Grove's pioneering and classic work on eco-history, Green Imperialism, and by some of the primary influences on Darwin's thinking. Amongst the sixteen major

5. Richard Grove, Green Imperialism: Colonial Expansion, Tropical Island Edens and the Origins of Environmentalism, I600-I860 (Cambridge, I995), which concentrates on the late eighteenth and early nineteenth centuries although noting efforts by Caribbean authorities in the seventeenth century to preserve their forests and protect edible sea birds. See p. 5.

6. Ibid.

7. Felipe Fernández-Armesto, "Refloating Atlantis: The Making of Atlantic Civilization", in idem, Civilizations: Culture, Ambition, and the Transformation of Nature (London, 2000), pp. 403-434; Luís Adão da Fonseca, "La découverte de l'espace Atlantique", Cadmos, 53 (I99I), pp. I I-2 s; idem, "Le Portugal entre la Méditerranée et l'Atlantique au XVe siècle", Arquivos do Centro Cultural Português, 26 (1989), pp. I45-160; and, more generally, idem, The Discoveries and the Formation of the Atlantic Ocean (Lisbon, 1999). 

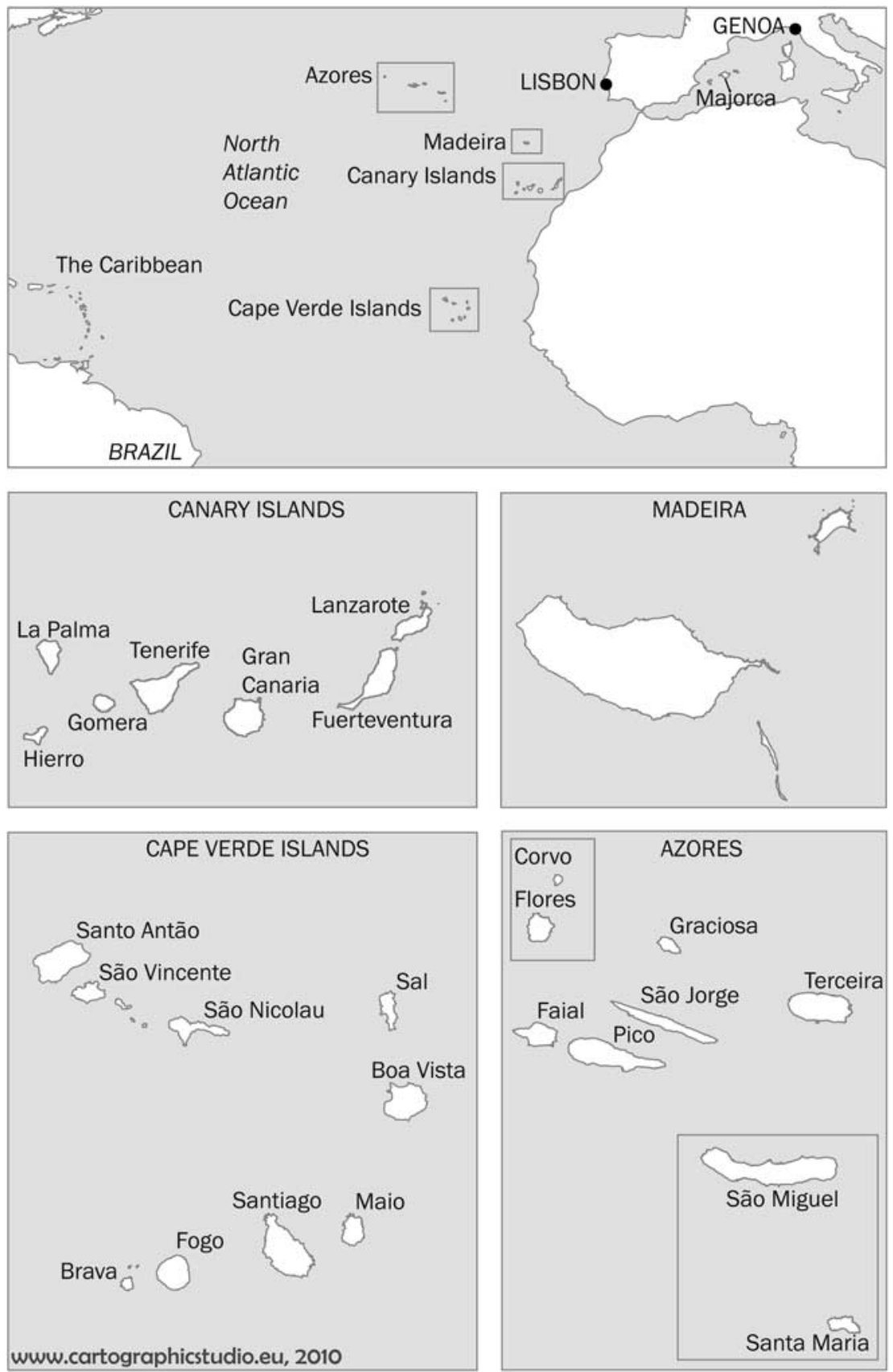

Figure I. Map of the mid-Atlantic archipelagos. 
books which Darwin carried with him on The Beagle was that by Alexander Beatson, an Indian army engineer, who published Tracts Relative to the Island of St Helena in I 8 I 6. This book includes a listing by William Roxburgh of the endemic plants of St Helena, commenting on their rates of extinction. ${ }^{8}$ Islands, because of their limited extent and aspect of confinement, became, Vinita Damodaran argues, "symbolic of the explored world, and encouraged ideas about limited resources and the need for conservation or sustainability".?

\section{"INSULAMANIA": THE MID-ATLANTIC ISLANDS AS UTOPIAN PROJECTIONS}

The pessimistic conclusions drawn by later commentators from the early modern encounter between humanity and the mid-Atlantic islands stand cheek by jowl with other, earlier texts bursting with excitement at the prospect of their rediscovery. The distinguished Florentine historian, Leo Olschki, built on a platform of literary texts from this period to make a case for "insulamania", island-mania on the geographical horizons of early modern humanity, perhaps most easily exemplified by the monstrously swollen proportions accorded the islands on Portuguese and other Mediterranean portolan charts, when compared to the continental land masses, and seamen queuing up for royal grants of land rights to islands still to be discovered. ${ }^{\circ}$ We would do well, furthermore, to draw attention to that genre of atlas - the isolarium - that specifically came into being around the end of the fifteenth century and, as Lestringant argues, is a fine expression of Renaissance "singularity" (see Figure 2). ${ }^{\mathrm{II}}$

"Insulamania" fused with the Christian search for Eden, which had traditionally been attributed, as we find on the Hereford Mappa Mundi of I 253 , to an island somewhere to the east, but also with the search by humanist philosophers like Thomas More and Mandeville for the ideal

8. Alexander Beatson, "An Alphabetical List of Plants, Seen by Dr Roxburgh Growing on the Island of St Helena, in I813-14", in idem, Tracts Relative to the Island of St Helena (London, I 8 I6), pp. $295-327$.

9. Vinita Damodaran, "Environment and Empire: A Major Theme in World Environmental History", in Mary N. Harris and Csaba Lévai (eds), Europe and its Empires (Pisa, 2008), p. I 32. Io. Leo Olschki, Storia letteraria delle Scoperte geografiche (Florence, 1937). See, for example, the grant of 2I June I 473 to Rui Gonçalves da Câmara in reward for his services in Africa of "an island that shall be found by himself or by his ships”, in Manuel Monteiro Velho Arruda, Colecção de documentos relativos ao descobrimento e povoamento dos Açores (Ponta Delgada, 1932), p. 4I. For more about the development of portolan charts, see Konrad Kretschmer, Die italianischen Portolane des Mittelalters, Ein Beitrag zur Geschichte der Kartographie und Nautik (Berlin, 1909). I I. Frank Lestringant, "Insulaires de la Renaissance", in Cartes et figures de la terre [catalogue of an exhibition held at the Centre Georges Pompidou] (Paris, I980), pp. 450-475; George Tolias, "Isolarii, Fifteenth to Seventeenth Centuries", in David Woodward (ed.), Cartography in the European Renaissance (Chicago, IL, 2007), pp. $263{ }_{3} \mathrm{ff}$. 


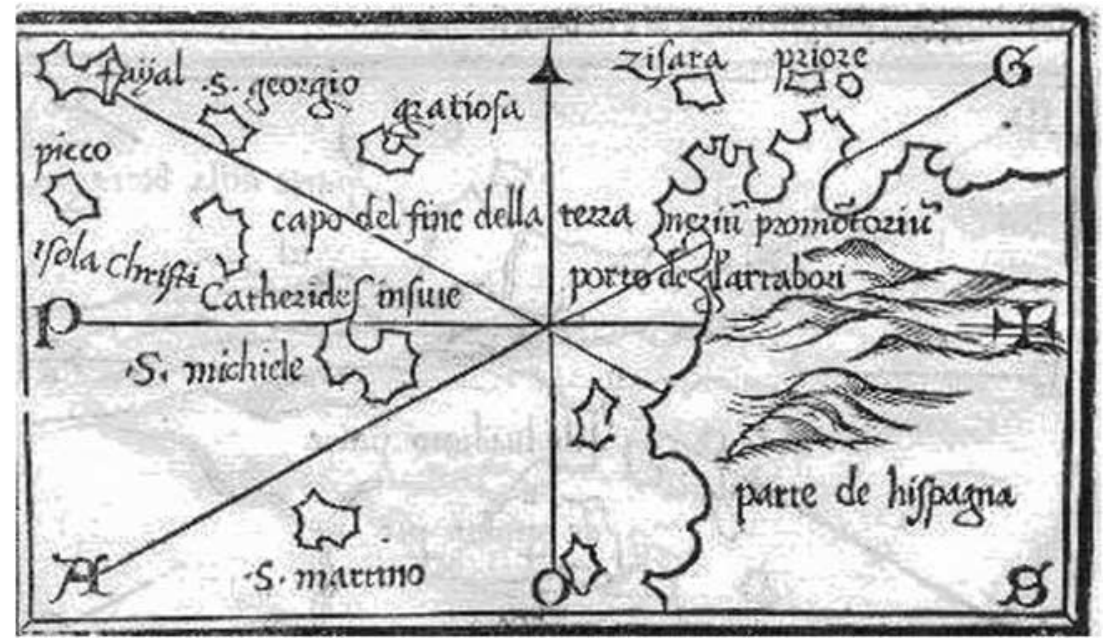

Figure 2. An isolarium.

Source: Isolaria di Benedetto Bordone nel qual si ragiona de tutte le Isole del mondo con li lor nomi antichi \& moderni, historie e fauole [...] (Venice, I 547).

William L. Clements Library, Ann Arbor. Used with permission.

society, which needed a certain degree of isolation to flourish. ${ }^{\mathrm{I2}}$ Finally, there were legendary traditions that attributed gold (a source of great fascination to European society during a century marked by the "bullion famine") to the sands of the Isle of the Seven Cities, from the early fifteenth century equated with the Azores. ${ }^{\mathrm{I}}{ }^{3}$ All of these factors led to a great deal of social expectation being placed on the mid-Atlantic islands in the fifteenth century and first half of the sixteenth century. For our purposes here, the fact that oceanic islands were perceived as highly desirable "Edenic" locations in long-running European cultural traditions serves to emphasize the shock of their manifest and rapid degradation.

Initial reports, then, only emphasize the natural bounty and wealth of these new discoveries. As the royal chronicler Damião de Góis starts out in his description of the Azores:

These islands are called Açores for their abundant nature [muita criaçam] when they were discovered, and that is still the case [...]. They are very temperate in

I 2. G.R. Crone has argued that the western location of the mid-Atlantic islands rendered them an "anti-paradise", a counterposition to the terrestrial paradise in the east. See Vitorino Magalhães Godinho, Mito e Mercadoria, utopia e prática de navegar: séculos XIII-XVIII (Lisbon, 1990), p. 244. Otherwise, Louis-André Vigneras, "La búsqueda del Paraíso y las legendarias islas del Atlántico", Anuario de Estudos Americanos, 30 (1973), pp. $809 f f$.

I3. See the map of around 1492 that Charles De La Roncière incorrectly attributed to Columbus: La carte de Christophe Colomb (Paris, 1924). For the bullion famine, see John Day, "The Great Bullion Famine of the Fifteenth Century", Past E Present, 79 (1978), pp. 3-54. 
winter and summer, and very luxuriant [viçosas] in springs and streams, with very good water, and fruits, especially thorny fruit [d'espinho] of all kinds. ${ }^{14}$

Study of the royal toponyms (toponimias reais) and early names set down in texts such as the Libro del Conocimiento by two anonymous Franciscans (written in c.1300) and on portolans such as the Zuane Pizzigano map of 1424 suggests that the rich natural resources of the islands were drawn upon to support this Edenic projection - Madeira meaning "wood", Canarias meaning "canaries", "Brasil" from its sappan wood, Columbária from its doves, Sal in the Cape Verde archipelago from its salt deposits, Açores meaning "hawks", Corvo for "crow", the Lobos Marinhos or "sea lion" islands in the proximity of the Canaries, etc. ${ }^{\text {Is }}$ Finally, we must imagine how the natural bounty of the islands, when compared with the empty sterility of the surrounding ocean surfaces, must have struck worldly mariners and voyagers such as Jan Huyghen van Linschoten and Pyrard de Laval as the very paradigm of an "earthly paradise". ${ }^{16}$

Somewhat more rarely, we find literary accounts that dismiss the state of nature of the mid-Atlantic islands, suggesting that nature needed to be modified so as to render these ilhas-refúgio - places for a saving mission for humanity - habitable and fit for human beings. The Machin or Machim legend, the adventures of an English nobleman escaping across the English Channel with his bride-to-be caught up in a storm, is one such. It recounts how the anti-hero, landing on Madeira by chance, found it a "forlorn place, both uncultivated and unpeopled". Only with the second, this time intended visit in I4I9 or I420 - here by the two "noble esquires" Zarco and Vaz - was the "wilderness converted into a Garden of Pleasure". ${ }^{17}$ Similarly, there is no

14. Damião de Góis, Crónica do Príncipe D. João (Lisbon, 1977), ch. 9. For some context, see Graça Almeida Rodrigues, "Tres visões históricas da colonização portuguesa no Atlântico: Góis, Cadornega e Maldonado", in Os Açores e o Atlântico (séculos XIV-XVII): actas do colóquio internacional realizado em Angra do Heroísmo de 8 a 13 de agosto de 1983 (Angra do Heroísmo, 1984), pp. 378-396.

I 5 . Marcos Jiménez de la Espada (ed.), Libro del conocimiento de todos los reinos, tierras y señorios, Boletin de la Sociedade Geográfica de Madrid, 2 (I877).

16. The Voyage of John Huyghen van Linschoten to the East Indies (London, I885), II, ch. 94, pp. 254-258; The Voyage of François Pyrard of Laval to the East Indies, the Maldives, the Moluccas and Brazil (London, 1887-1890), II, pp. 296-302.

17. William Ovington, A Voyage to Suratt in the Year 1689 (London, I696), p. 5. The Machin legend was first set down by Valentim Fernandes da Morávia, a German printer living in Lisbon in the early sixteenth century. See António Baião (ed.), O Manuscrito "Valentim Fernandes" (Lisbon, 1940). A parallel, but seemingly independent record of the story appeared in a tract written by António Galvão, Tratado dos descobrimentos antigos e modernos (Lisbon, I563), trans. Richard Hakluyt as The Discoveries of the World (London, I601). A further version in résumé form appears in Francisco Manuel de Melo, Epanáforas da vária História Portuguesa (Lisbon, I660), professing to use the original, an account by a squire of Prince Henry who later accompanied Zarco on that "first” voyage. According to Melo's account, Machin dies after this first visit, but his story is passed on, via a Sevillian pilot, to Zarco, the first colonizer. 
denying the anonymous chronicler of the Conquista de la isla de Gran Canaria the satisfaction with which he relates how the first governor, Pedro de Vera, once the island was finally subjugated in 1483 , brought from Spain "fruit trees, sugar cane, vegetables and livestock" (árboles frutales, cañas de azúcar, legumbres y ganados) and from Madeira "sugar mill technicians and harvesters" (maestros y cosecheros de azúcar). ${ }^{\mathrm{I}}$

\section{THE FIRST STAGES OF COLONIZATION: FOREST- CLEARING AND SETTLEMENT STRATEGIES}

Even the Edenic visions invariably regarded human colonization as the end result of the process of discovery, and it was not long before the forests of Madeira and the Azores were both put to fire to clear the land for agricultural usage and cut down for use as timber. The fires on Madeira, as the chronicler Zurara recounts the tale, became so fearfully hot that the islanders under their Capitão, Zarco, were obliged to take to their boats (costretto nel mar fuggire) to escape the flames which, with considerable exaggeration, were reported to have consumed the island for seven years. ${ }^{19}$ Traces of the former forest (matagal) that covered the island can still be seen on the north shore of the island, now covered predominantly by a kind of scrub pine (pinus lauris), and may indeed have deliberately been left to furnish planks from which boxes to hold the export sugar product (caixas de açúcar) were made.

In the Azores, where the same deforestation occurred, the trees cut down were principally cedars, but also laurels, dwarf cherry trees (ginjas), beeches, and several other species. ${ }^{20}$ After the earthquake of 1630 , the wooden roof of Vila Franca's Matriz church was built from cypress trees from Furnas; this was probably the last time virgin timber was used for construction on São Miguel. Today, as the historical geographer Soeiro de Brito reports, trees can be found only in "the bottom of some profound depression (grota) in the earth, in strips of hardly accessible upland (arribas), or on crinkled (rugosas) stretches of earth marked by recent lava flows". ${ }^{2 \mathrm{I}}$

The Canaries were similarly forested, despite their inhabitants, particularly the western islands - El Hierro was praised in the Norman chronicle of 1402 Le Canarien for its "large groves (boccages grands), which are green in all seasons (of) a hundred thousand pine trees, most of

I8. B. Bonnet and E. Serra Rajols (eds), Conquista de la isla de Gran Canaria. Crónica anónima (La Laguna, 1933), p. 40.

19. Benedetto Bordone, Libro de tutte l'isole del mondo (Venice, I528), p. I sv; cf. Gomes Eannes de Azurara, Chronicle of the Discovery and Conquest of Guinea (London, 1896-1899), II, pp. xcix-c.

20. Gaspar Frutuoso, Saudades da Terra (Ponta Delgada, I822-I83I), book 4, I.

2. R. Raquel Soeiro de Brito, No trilho dos Descobrimentos: estudos geográficos (Lisbon, 1997), p. 29. 
which are so thick that two men can hardly make their arms meet round them". ${ }^{22}$ They were similarly subjected to slash-and-burn tactics (derrubas e queimadas), to the point that the visitor Thomas Nicols could write, concerning Gran Canaria in the I 560s, that "wood is the thing that is most wanted". ${ }^{23}$

Island councils were quick to broach this issue, concerned that what was both a source of income and a fragile resource was endangered. Every form of exploitation required a licence, and a number of caveats were put in place: the cutting of trees near springs was prohibited; no trees that were large enough for construction were to be taken for fuel wood; ten new trees were to be planted for each pine removed; livestock were prohibited from entering the forest, and fires were outlawed, as was night hunting in the dry season. Certain species, such as aceviño, a kind of holly (ilex canariensis), were explicitly prohibited, and areas such as the Montañas de Doramas of Gran Canaria were protected. Export was closely controlled and at times prohibited, with severe fines for violation. ${ }^{24}$

This wave of unparalleled legislation (at least from a Portuguese perspective) may have had positive repercussions in the short term, but it was not substantial enough to halt the wave of continued exterminio in later centuries, no more so than during the last two world wars. Günther Kunkel estimates that the laurel forest (laurisilva) cover currently occupies less than I per cent of its original area. ${ }^{25}$

The deforestation of Madeira was taken by many contemporary authors as an example of destruction and turning nature into wilderness. Hakluyt, for example, considered the process in the same light as that which had happened to the English colony of Virginia. ${ }^{26}$ Some historians

22. The Canarian: Or, Book of the Conquest and Conversion of the Canarians in the Year I402, Messire Jean de Béthencourt, trans. and ed. with notes and an introduction by Richard Henry Major (London, 1872), p. 74.

23. Thomas Nicols, A Pleasant Description of the Fortunate Ilandes, Called the Islands of Canaria (London, 1583 ), p. $6 \mathrm{v}$.

24. José Peraza de Ayala, Las ordenanzas de Tenerife, 2nd edn (Madrid, 1976); Leopoldo de la Rosa, Catálogo del Archivo Municipal de La Laguna (Sucesor del antiguo cabildo de Tenerife), Revista de Historia (Universidade de La Laguna), various issues, 1944-1960; Acuerdos de Cabildo de Tenerife, in Elias Serra Rafols and Leopoldo de la Rosa (eds) Fontes Rerum Canarium IV: 1497-I507, I949; V: I 509-I513, I952; XI: I514-1518, I965; XVI: I I18-1 525, 1970 (La Laguna); Francisco Morales Padrón, Ordenanzas del Consejo de Gran Canaria, I53 I (Seville, I974); Pedro Cullén del Castillo (ed.) Libro Rojo de Gran Canaria (Las Palmas, I947); Leopoldo de la Rosa, Evolución del régimen local en las Islas Canarias (Madrid, I946). More generally, Alfredo Piqué, "La destrucción de los bosques de Gran Canaria a comienzos del siglo XVI”, Aguayro, 92 (1977), pp. 7-10.

25. Günther Kunkel, Die Kanarischen inseln und ibre Pflanzenwelt (Stuttgart, 1980), pp. 85-86.

26. Richard Hakluyt, "A Notable Historie Containing Foure Voyages made by certain French Captaines into Florida [...]", in idem, The Principal Navigations, Voyages, Traffiques and Discoveries of the English Nation made by Sea or Overland to the Remote E Farthest Distant 
have gone far in assessing the impact of such savage forest depletion, arguing on this basis for the wholesale shift in the regional economy; observers of similar fires, such as the one which raged on Cephalonia in the Ionian sea in I797, and could be seen as far away as Zante, suggested that consequently the climatic regime of the island became palpably less equable. ${ }^{27}$

But the forest-burning episode perhaps casts too large a shadow over subsequent realities. Fine furniture continued to be produced in Madeira from the local yew and cedar and exported to Portugal in such abundance that "loftier dwellings" (grandes alturas das casas, que se vaão ao ceeo) started to become the norm back in Portugal and to the point that "almost all Portugal" became adorned with tables and other furniture made from the wood of Madeira. ${ }^{28}$ Many of the hard woods - til (stinkwood), barbuzano (ironwood), teixo (yew), and vinhático (Brazilian mahogany) continued to be supplied to the mainland for the purposes of large-ship building, for which it was ideal. ${ }^{29}$ The magnificent dragon tree (Dracacea draco), which provided red dye for the textile industry, remained..$^{30}$

Otherwise, the ashes contributed to a rich soil that allowed vines and cereal crops to flourish, at least initially before the soil became exhausted and an unnamed nobleman from Brittany was called upon to impart new techniques, namely a kind of fallow regime (fertilização pelo tremeço enterrado em verde). ${ }^{3 \mathrm{I}}$ Wheat, for example, which did so well on Madeira from the I 430 s to the late I460s, whence it was exported to black Africa, dropped off subsequently and ceased to be exported; indeed, since then the island has been a wheat-deficit area, having to import from the Azores in 1516 , where the early harvests "caused astonishment" (espanto). ${ }^{32}$

Quarters of the Earth at any Time within the Compasse of these I600 Years, 8 vols (London, 1926), VI, p. 229.

27. Fernand Braudel, The Mediterranean and the Mediterranean World in the Age of Philip II (London, I972), pp. I4I-I44; Othon Riemann, Recherches archéologiques sur les îles ioniennes (Paris, I879), p. 4.

28. Thomas Bentley Duncan, Atlantic Islands: Madeira, the Azores, and the Cape Verdes in Seventeenth-Century Commerce and Navigation (Chicago, IL, I972), p. I0; Gomes Eannes de Azurara, Chrónica do descobrimento e conquista de Guiné (Paris, I84I), p. I4; Gerald R. Crone (ed.), The Voyages of Cadamosto and Other Documents on Western Africa in the Second Half of the Fifteenth Century (London, 1937), p. 9.

29. Jerónimo Dias Leite et al., Descobrimento da Ilha da Madeira e Discurso da Vida e Feitos dos Capitães da dita Ilha. Tratado composto em I579 e agora publicado (Coimbra, 1947).

30. The Voyages of Cadamosto, op. 7. Ca' da Mosto is usually cited from the corrupt but more accessible text in Giovanni Battista Ramusio's Navigationi et viaggi (Venice, I550-I558); a better one, first published in Francanzano da Montalboddo's Paesi nouamenti retrouati (Vicenza, I 507), is reproduced in António Brásio, Monumenta missionaria Africana: Africa Ocidental, 3 vols, ser. II (Lisbon, 1963-), I, pp. 287-374.

31. Ernesto do Canto (ed.), Archivo dos Açores, IV (Ponta Delgada, I882), p. I69.

32. Raquel Soeiro de Brito, A Ilha de São Miguel. Estudo Geográfico (Lisbon, I955), p. 68. 
"Massive" soil erosion was another problem that occurred in the wake of forest clearance, as was true in Barbados and Jamaica after i 560.33

And yet enough farmland remained for Madeira to win the epithet "Queen of the Islands" for its abundance in comestibles, quickly becoming an indispensable base or stopping-off point safeguarding the extension of Portuguese trade routes around Africa and towards the Orient. The Portuguese explorer of West Africa, Antão Gonçalves, for instance, made repeated stops at Madeira during his expeditions in I44I and $\mathrm{I}_{44} 2$ "because of the great supplies (mantiimentos) that there were". ${ }^{34}$ Writing in I455, the knowledgeable Venetian Alvise Ca' da Mosto marvelled at the "vines the Infante had planted [...] brought from Candia at his orders", and which $\mathrm{Ca}$ ' da Mosto described as "the finest sight in the world". ${ }^{35}$ Wines, alongside wheat, salt and sugar, were the chief international export goods from the Canaries, as interesting analysis of inquisitorial interrogations of ninety-one foreign sailors between I 558 and 1598 reveals. ${ }^{36}$

Forest was not the only foundation stone of mid-Atlantic nature to be sacrificed on the Europeans" arrival. We might mention the "sea wolves" (lobos marinhos) or sea lions, slaughtered by Gonçalves Baldaia and his crew from amongst a colony estimated at around 5,000 animals, "with abandon [...] because they were easy to kill"; ${ }^{37}$ Vasco da Gama did much the same on a colony of seals he came across, firing at them with the ship's cannon and killing penguins too "as was our [sic] will".$^{38}$ But before them, the arrival of the Guanche aboriginals too had led to the extinction of certain large reptiles and insular mammals, including the giant lizard, Lacerta goliath (which attained one metre in length), and Canariomys bravoi, the giant rat of Tenerife.

While ecologists acknowledge that extinction is a complement to evolution in order to make room for new species to evolve, and thus a positive factor, they have struggled to determine an appropriate "natural" pace for what they would like to call "background levels of extinction". One scientist, David Jablonski, a palaeontologist, has estimated background levels at "perhaps a few species per million years for most kinds of organism". 39 European intrusion invariably heightened this pace, although not to the full extent of deep pessimists such as Alfred Russell

33. David Watts, The West Indies: Patterns of Development, Culture and Environmental Change since 1492 (Cambridge, 1987).

34. Azurara, Chrónica do descobrimento, p. I64.

35. The Voyages of Cadamosto, p. Io.

36. Maria Berenice and Moreno Florido, "Rutas comerciales atlánticas: una aproximación inquisitorial”, Jahrbuch für Geschichte Lateinamerikas, 4I (2004), pp. 39-63.

37. Azurara, Chrónica do descobrimento, p. 64.

38. Alváro Velho, Diário da Viagem de Vasco da Gama: facsimile do códice original transcrição e versão em grafia actualizada (Oporto, I945), I, p. Io.

39. David Jablonski, "Background and Mass Extinctions: The Alternation of Macroevolutionary Regimes”, Science, 23 I (1986), pp. I29-133. 
Wallace, who feared that the arrival of "civilized man" to the "virgin forests" of the Malay archipelago would "disturb the nicely-balanced relations of organic and inorganic nature" to the point of thorough extinction..$^{40}$

Then there are the consequences of newly arrived fauna brought to the islands, particularly rabbits. A single, pregnant rabbit was set loose by the first captain of the Madeiran island of Porto Santo, Bartolomeu Perestrello. The descendants of the rabbit flourished and multiplied so exceedingly that within a few years they had infested the whole island, decimating the crops "as if a punishment (amoestação) from God", as the chronicler João de Barros writes. ${ }^{4 \mathrm{I}}$ All attempts to eradicate them failed, and the settlers became unable to sow anything (nom podyam semear nhĩa cousa) and were forced to take to Madeira, fifty kilometres to the south-west. When they returned, they abandoned agriculture in favour of rearing cattle. ${ }^{42}$ Other rabbits were brought to La Palma by Don Pedro Fernández de Lugo, the second Adelantado, or Lieutenant-Governor, of Tenerife. After the persistent drought of I 545, they apparently grazed all the tree shoots and herbs at the top of the Caldera de Taburiente, after which the upper part of the island remained "quite bare and desolate". ${ }^{43}$

Generally speaking, and in comparison to the ease with which Madeira was settled and colonized within two generations, or the high and balanced productive output which was attained on the two large islands of the Canaries, Tenerife and Gran Canaria, the settlement process of the nine islands of the Azores was a "lengthy, intermittent and hesitant process" ${ }^{44}$ Here, the clearing met with mixed success. André Thevet explains how

$[\ldots]$ of these islands, some are inhabited that before were deserted, and many are forsaken that in times past were inhabited and peopled, as we see hath happened to many cities and towns of the Empire of Greece, Trapezande and Egipt, such is the ordinance of God, that things heere in earth shall not be perdurable, but subiect to changing. ${ }^{45}$

On some of the islands, Flemish landowners like Joz de Utra (van Huerter), together with their serfs and companions, were attracted by

40. Alfred Russel Wallace, The Malay Archipelago (New York, 2007) (first publ. I 869), p. 340. 41. João de Barros, Da Ásia, Década I, livro I, f. 6-8 (Lisbon, I552).

42. Azurara, Chrónica do descobrimento, p. 387.

43. George Glas (trans. and ed.), The History of the Discovery and Conquest of the Canary Islands (London, I764), p. 266.

44. Duncan, Atlantic Islands, p. I I.

45. André Thevet, The new found vvorlde, or Antarctike wherin is contained wo[n]derful and strange things, as well of humaine creatures, as beastes, fishes, foules, and serpents, trées, plants, mines of golde and siluer: garnished with many learned aucthorities, tranailed and written in the French tong, by that excellent learned man, master Andrevve Theuet. And now newly translated into Englishe, wherein is reformed the errours of the auncient cosmographers, trans. Henrie Bynneman (London, I 568), ch. 83, I36v. 
generous land grants and tax concessions, in the words of one privilege on tithe and portage for products exported from the islands "so that the islands may be well populated". ${ }^{6}$ In 1468 Utra founded the town of Horta, on Faial. One landowner, Wilhelm van der Haegen, an erstwhile merchant of Bruges, was granted the island of São Jorge, but had to abandon it for lack of profit. ${ }^{47}$ In others, colonization had to be supplemented by the forced exile of criminals, though official deportation orders appear to have been rescinded. In I453, for example, a sentence of life exile to São Miguel was commuted to exile in Ceuta. ${ }^{4}$ Historians have analysed this turnaround in different ways. Timothy Coates thinks that the islands were ultimately able to attract a sufficient number of free colonizers, and could thus dispense with degredados, while more scrupulous research suggests that the revocation of the order was made on the basis that life itself was so tenuous there that this decision was simply considered too harsh. ${ }^{49}$ One group of Flemish colonists were so bitterly disappointed (denojados) that they wanted nothing less than to kill their captain. ${ }^{5 \circ}$

\section{ECONOMIES OF EXPLOITATION}

As we shall see later on, much of the initial economic exploitation was the harvesting of indigenous rock dyes and conchas marinas (marine shells, including cowries), sent on to the coasts of Guinea where they were used as a form of currency. A lot of the land was simply left for pasture. Sending out cattle, for example, was the initial development strategy of the Captain Donatory of Porto Santo, Perestrello, with regard

46. King Afonso's charter to Dom Pedro for the Azorean island of São Miguel is in Arruda, Colecção de documentos relativos ao descobrimento. For more on the Flemish in the Azores, see J. Mees, Histoire de la découverte des îles Açores et de l'origine de leur dénomination d'îles flamandes (Ghent, I90I). The charter of the island of Terceira to Prince Henry's "servant" (servidor) Jacome de Bruges stipulated rights for colonists "of his [Jacome's] choice”, provided that they were Catholics. See the charter of 2 March 1450 in João Martins da Silva Marques (ed.), Descobrimentos portugueses: documentos para a sua história (Lisbon, I944), I, 40I, no. 315 .

47. António dos Santos Pereira, A Ilha de S. Jorge (séculos XV-XVII) (Ponta Delgada, 1987). 48. Document dated I2 March I453 in João Martins da Silva Marques, Descobrimentos portugueses; documentos para a sua história, 2nd edn (Lisbon, I988), II, 344, no. 223.

49. Timothy Coates, Convicts and Orphans: Forced and State-Sponsored Colonizers in the Portuguese Empire, I550-I755 (Stanford, CA, 200I), p. 61; Peter Russell, Prince Henry "The Navigator": A Life (New Haven, CT, 2000), p. I03, based on Monumenta Henricina (Coimbra, 1960-1975), IX, no. 242. The wording of the 1453 commutation explains: "because the said islands were not such that men could sustain life".

50. See the cartouche for "Ylha do Fayal e Pico" on the Behaim globe, as transcribed by E.G. Ravenstein, Martin Behaim: His Life and His Globe (London, I909), which explains the revolt as provoked from disappointment that neither silver nor tin deposits were found (denojados que nom acharom o que lhes foy promettido). 
to the Desertas islands, "intending to have them peopled like the other [island of Porto Santo]". ${ }^{\text {I }}$ The first note we have regarding the colonization of the Azores is a royal instruction (carta régia) of D. Alfonso V of I439 to send sheep to the seven islands. ${ }^{52}$ Large grazers (gado grosso) and pigs tended to be introduced after goats and sheep, hardier and more independent, and with them slowly developed tanning industries (curtumes).

Cereals such as wheat, barley, and rye - considered by historical geographers to constitute "more complex agriculture" - were grown from early on in the Azores, reflected in mundane commercial charters concerning the building of windmills and the baking of bread. Góis relates the abundance with which the farmers were rewarded: "oft times the peasants harvested from one alqueire of seed twenty or thirty".53 As a consequence, the best land on the islands tended to be given over to this activity. However, while early reports suggested that there was "so much wheat produced on São Miguel that each year a number of boats arrive in order to load wheat to send to Portugal", and that some was sent to relieve famines in the Portuguese presidios in North Africa, such as Azemmour in $\mathrm{I} 488$, on other islands we find petitions from concerned citizens requesting the prohibition of grain exports, as happened in the town of Velas on the island of São Jorge in I 59I, which suggests that even self-sufficiency was a struggle to attain. ${ }^{54}$

More often than not, however, the export of Azorean grain was "independent" of the requirements of local needs and supply, and attuned rather to prices that it could command on international markets. ${ }^{55}$ Price series confirm both a general upward trend and decades marked by astonishing rises; one finds, for example, a I7I.4 per cent appreciation between I 584 and I $594 .{ }^{56}$ Not all of this, however, was straightforward outside demand. As a Madeiran petition of i 563 explains, the problem lay

51. Azurara, Chrónica do descobrimento, p. 391.

52. Gaspar Frutuoso ascribes the same strategy to an anonymous Greek colonist of São Miguel in the Azores around the year 1370, although the story is almost certainly fanciful in its historical veracity if not in the idea or intention. See Gaspar Frutuoso, Saudades da Terra (Ponta Delgada, 2005), livro IV, p. 5 .

53. Góis, Crónica do Príncipe D. João, p. 28. In Mito e Mercadoria, pp. 245-246, Godinho estimates that production was 5,000 moios, which later rose to I 5,000 moios (sufficient to feed between 75,000 and 200,000 mouths). In the I 580 s, this figure rose beyond 20,000 moios, and hovered around 40,000 moios at the beginning of the eighteenth century.

54. Joel Serrão, "Le Blé des Îles Atlantiques. Madère et Açores aux XVe et XVIe siècles", Annales. ESC, 9 (1954), pp. 337-34I; Pereira, A Ilha de S. Jorge, p. I52.

55. M. de Assis Tavares, "A Pobreza na Ribeira Grande durante a Segunda metade do século XVI”, Arquipélago (1983), Numéro Especial, p. 5 I.

56. A.H. de Oliveira Marques, "O preço do trigo em S. Miguel no século XVI", Revista de Economia, I4:4 (I962), pp. 213-266; Vitorino Magalhães Godinho, “A 'revolução dos preços' e as flutuações económicas no século XVI”, in idem, Ensaios, 2nd edn (Lisbon, I978), II, pp. $223-245$. 




Figure 3. Land use on São Miguel island in the sixteenth century.

with those who owned the grain, for "the greater part of those who, on the said Azores islands, possess bread are judges and aldermen (vereadores) and landowners, who order the gates (portas) of the said islands to be closed by municipal order (por suas posturas) whenever they want", so as to keep the price of their stocks buoyant. ${ }^{57}$

It is worth looking at the following map (see Figure 3) showing generalized land use on the island of São Miguel..$^{8}$ We can consequently judge for ourselves how limited human invasive agriculture was, despite the sesmaria laws by which grants of land would be rescinded if the land were not cultivated; we can estimate the proportion of land exhibiting invasive agriculture at around one-fifth.

At this point, I would like to investigate a little more closely the impact of subsequent sugar cultivation on the mid-Atlantic island ecosystems. The transplanted sugar industries from southern Spain and Sicily were an instant success in the mid-Atlantic, where they spread from Madeira (c. I 425 ) and the Canary Islands to the Azores and Cape Verdes. ${ }^{59} \mathrm{Ca}^{\prime} \mathrm{da}$ Mosto, who visited Madeira in I455, then estimated production at about 400 pitchers or cantaros - about 60,000 lbs. He correctly foresaw the rapid development of the industry on the island, aided by the balmy and

57. Cited in Godinho, Mito e Mercadoria, p. 246.

58. Soeiro de Brito, No trilho dos Descobrimentos.

59. María Luisa Fabrellas, "La producción de azúcar en Tenerife", Revista de Historia, i 8 (1952), p. 47I; G. Camacho y Pérez Galdós, "El cultivo de la caña de azúcar y la industria azucarera en Gran Canaria (I I I0-I 535)”, Anuario de Estudos Átlanticos, 7 (1961), pp. I I-70. 




Figure 4. Land use on Madeira at the end of the sixteenth century.

moist climate (see Figure 4). Madeiran sugar became a global commodity, to be found in the markets of Bristol and Flanders in the late I460s, later sent as far afield as Pera on the Black Sea, Chios, and Constantinople. The deputies of the Portuguese Cortes of I48I-I482 extolled the economic success of the Madeiran islands, enumerating the "twenty forecastle ships and forty or fifty others which loaded cargoes chiefly of sugar, without counting other goods and other ships which went to the said islands [...] for the nobility and richness of the merchandize of great value which they have and harvest in the said islands". ${ }^{60}$

By I 500 , Madeira was the world's leading producer and consequently attracted investments from the two most developed regions of the world, northern Italy and Flanders. An account book of I494 of the Superintendency for Sugar in the capitania of Funchal entitled Livro do Almoxarifado Açuquarres das Partes do Funchal stipulates a booming supply of 100,000 arrobas ( 3.2 million lbs), halcyon days before disease and imposed export ceilings struck the industry in the early sixteenth century. It also sheds light on the scale of production, which was in the hands of small- and medium-sized producers and was not large-scale 
production, as had been previously supposed. ${ }^{61}$ Documents from the Câmara de Funchal dated I493 and included in Frutuoso's chronicle, Saudades da Terra, suggest an output of 80,000 arrobas in the hands of 80 mestres de fabrico on the island, suggesting that there were about this number of mills (engenhos). ${ }^{62}$

Sugar-cane plantations prospered in only some of the mid-Atlantic islands. After about I450 Madeira was the leading supplier, but over the course of the sixteenth century it was overtaken by São Tomé, where an anonymous Portuguese pilot estimated production of as much as I 50,000 arrobas by 50 engenhos in C.I $554 .{ }^{63}$ By the 1500 s the Canary Islands had also become important, with I 2 sugar mills on both Tenerife and Gran Canaria in the I560s (perhaps substantially more earlier), 4 on La Palma, and I on Gomera ${ }^{64}$ If sugar showed signs of prosperity on São Miguel in the Azores around I 560, it never really took off - Gaspar Frutuoso in I 589 stated that the climate was too humid for the mills, but there was already by this time strong competition from Brazil, lack of wood for production, and the appearance of a parasite (bicho) which destroyed crops. ${ }^{65}$ Tobacco did better here. But the production techniques the Iberians mastered here with respect to sugar saw the islands being used as "stepping stones" to implanting sugar monocultures in Brazil. ${ }^{66}$ Both Spain and Portugal experienced a growth of demand for their sugar, evident in the plummeting European prices for the product, which halved over the second half of the fifteenth century, but which did not affect the island's strong growth in exports. ${ }^{67}$

6I. Almoxarifado do açúcar do Funchal (1494), Arquivos Nacionais da Torre do Tombo, Lisbon, Núcleo Antigo, no. 57I, published in Fernando Jasmins Pereira et al., Livros de Contas da Ilha da Madeira, 2 vols (Coimbra, 1985-1989). For the myth of "large properties", see S. Greenfield, "Madeira and the Beginnings of New World Sugar Cane Cultivation and Plantation Slavery: A Study in Institution Building", Annals of the New York Academy of Sciences, 292 (1977), p. 544.

62. Álvaro Rodrigues de Azevedo (ed.), Saudades da Terra (Funchal, I 873).

63. "Navigatione da Lisbona all'isola di San Thomé, posta sotto la linea dell' equinoziale, scritte per me, pilotto portoghese e mandata al magnifico conte Rimundo della Torre, gentiluomo Veronese, e tradotta di lingua portoghese in italiano", in Giovanni Battista Ramusio, Navigazioni e viaggi (Turin, I978-I988), I, p. 306.

64. Camacho y Pérez Galdós, "El cultivo de caña de azúcar”, pp. i I-6o; see also Fabrellas, "La producción de azúcar en Tenerife", pp. 455-475.

65. Soeiro de Brito, A ilha de São Miguel. Estudo Geográfico, p. 73.

66. Frédéric Mauro, Le Portugal et l'Atlantique, an XVIIe Siecle (I570-I670): étude economique (Paris, 1960).

67. For a comparison of European sugar prices, see "O Império do Açúcar", in João Lúcio de Azevedo, Epocas de Portugal Económico, 3rd edn (Lisbon, 1973), pp. 222-223. We can admire the island's growth in sugar exports from the Saragossa decree of 2 I August I498, published in Arquivo Histórico da Maadeira. Boletim do Arquivo Distrital do Funchal, série documental III, XVII (1973), doc. no. 22; Henrique da Gama Barros, História da Administração, X (Lisbon, I945-1954), p. I56. 
What effects did growing sugar intensively have on the soil of the islands? This is a question entirely absent from the otherwise classic summaries of the industry, such as that by João Lúcio de Azevedo. In the Recôncavo da Bahía local environmental damage was considerable, especially in terms of deforestation for crop planting. ${ }^{68}$ There is also the question of forest-clearing for wood to heat the enormous copper cauldrons which were needed to boil the cane for six months of the year. Although forest clearing for the engenbos had a large impact on the mid-slopes of Tenerife and Gran Canaria, the mills in Madeiran sugar production were powered via complex irrigation systems known as levadas, which channelled water across steep and difficult terrain to the mills. The Madeiran levadas formed a technical response to the desiccation that occurred particularly in the Canary Islands. ${ }^{69}$

In terms of soil effect, each plantation was continued for between five and ten, sometimes even twelve, years, with a fallow period (pousio) between each plantation of between two and three years sufficient to rejuvenate the earth. ${ }^{70}$ We would do well to remember that sugar production was merely a cycle in the islands' history, one that readily gave into a third cycle of international trade for Madeira that we have hinted at earlier, also true for the Canaries and Pico and Fayal in the Azores, namely the production of wines. This, once it had got going from the mid-sixteenth century, represented the staple export to the English plantations in North America and the West Indies, while Portuguese fleets took Canarian wines to Angola and Brazil. ${ }^{71}$ Meanwhile, on Madeira, sugar production dropped from a peak of 144,000 arrobas annually in I 506 to around 45,000 arrobas at the end of the sixteenth century as if to accommodate this spread of viticulture. ${ }^{72}$

Some of the "crops" hardly impinged on the local ecosystems. Orchil (aka archil or urzela) is a reddish dye (but blue in alkaline $\mathrm{pH}$ areas) extracted from indigenous lichens of the Roccella and Lecanora genera, growing naturally on rocks and cliff-sides on all of the nine main islands of the Azores and on its various offshore islets. Orchil figured in Prince Henry's will, and continued to be exploited for centuries. Gathering it, however, was a difficult and dangerous occupation on account of the

68. Peregrine Horden and Nicholas Purcell, The Corrupting Sea: A Study of Mediterranean History (Oxford, 2000), p. 334 .

69. Fernando Augusto da Silva and Carlos Azevedo de Menezes, "Levadas", in idem (eds), Elucidário Madeirense, 3rd edn (Funchal, 1965), II; Elof A. Ostman Norrl, "On Irrigation in Madeira", n.d., Manuscript in the Arquivo da Câmara Municipal do Funchal. The first document referring specifically to irrigation on the island is dated $\mathrm{I} 46 \mathrm{I}$.

70. Soeiro de Brito, No trilho dos Descobrimentos, p. $4 \mathrm{I}$.

71. Duncan, Atlantic Islands.

72. Estimates taken from Vitorino Magalhães Godinho, Os descobrimentos e a economia mundial (Lisbon, 1963-1968), III, pp. 419-456. Compare this with sugar production in Gran Canaria: the same author estimates the production of the 24 engenhos at around I 20,000-I 40,000 arrobas. See Mito e Mercadoria, pp. 245-246. 
rocks and cliffs on which Roccella grew, with gatherers suspended on ropes over ledges. ${ }^{73}$ However, substantial quantities of this dyeing agent were collected. In a few days, eight Spanish orchil-gatherers brought to the Cape Verde islands in I73 I collected a cargo of 500 quintals $(29,375 \mathrm{~kg})^{74}$

Some scholars have argued that attempts to cultivate orchil elsewhere in the Canary Islands as an alternative, like woad, to eastern supplies of indigo, failed, both due to a harsher, drier climate and due to the continued difficulties in subduing the Guanche populations. ${ }^{75}$ Their findings are contradicted by sources like Ludovico Guicciardini, in his description of the trade of Antwerp in I567, where he specifies that Spain supplied "Orcille of Canaria, which is an herbe to die with, called of the Florentines Raspe".$^{76}$ It was exported via Antwerp to manufacturers in England and Flanders. Portugal, too, supplied orcille "from their own country" to Antwerp. Orchil cultivation in the Canary Islands, then, was probably just a singular failure of Prince Henry's expeditions in the mid-I450s. Later, rich beds of orchil were discovered in the Cape Verdes, and even in Angola, where it grew on trees. ${ }^{77}$

Another introduced dye-plant was woad (pastel), of which production, like other raw materials in proto-industrializing areas of northern Europe, especially in England, Normandy, Brabant, but also bustling Lombardy, was declining at the end of the Middle Ages. ${ }^{78}$ Seeds (sementes) were imported from France, and techniques of its cultivation were passed on from Flanders via a certain Govarte Luiz. ${ }^{79}$ It was a valuable crop on

73. Maria Olímpia da Rocha Gil, "A economia dos Açores nos séculos XV e XVI”, in Luís de Albuquerque (ed.), Portugal no Mundo (Lisbon, 1989), I, p. 226; Annette Kok, "A Short History of the Orchil Dyes", The Lichenologist, 3 (1966), pp. 248-272. The Florentine noble family the Rucellai had originally discovered the plant's qualities in the thirteenth century on business ventures into the Levant. See Leandro Maria Bartoli and Gabriella Contorni, Gli Orti Oricellari a Firenze: un giardino, una città (Florence, 1990), p. 4.

74. Jean P. Hellot, L'Art de la teinture des laines et des étoffes de laine en grand et petit teint (Paris, 1750); see also Edward Bancroft, Experimental Researches Concerning the Philosophy of Permanent Colours, 2nd edn (London, I 8 I 3 ), p. 294.

75. Peter Russell, "Prince Henry and the Necessary End", in idem, Portugal, Spain and the African Atlantic, 1343-I490: Chivalry and Crusade from John of Gaunt to Henry the Navigator and Beyond (Aldershot, I995), p. Io; David Abulafia, "L'Economia italiana e le economie mediterranee ed atlantiche", in Francesco Salvestrini (ed.), L'Italia alla fine del Medioevo: $i$ caratteri originali nel quadro europeo (Florence, 2006), pp. 355-380.

76. Lodovico Guicciardini, The Description of the Low Countreys (London, I 593), p. 38.

77. Anon., "Orseille", in Encyclopédie du Dix-Newvième Siècle (Paris, I853), XVIII, pp. I38-I 39 .

78. Elizabeth M. Carus-Wilson, "La Guède française en Angleterre: un grand commerce du Moyen Âge", Revue du Nord, 35 (1953), pp. 89-105.

79. Francisco de Faria e Maia, Capitães dos Donatários (I439-I766). Subsídios para a História de S Miguel (Ponta Delgada, 1949), p. 26. 
which foreign businessmen like Lucas de Cacena made their fortunes. Initially in Sevillian Genoese (an area of important woad production), Cacena moved to Angra on the island of Terceira. Although hard data on the production of woad in the Azores are hard to come by, Cacena's evident success was rewarded by him being made a fidalgo da casa del rei by King João III. ${ }^{8 \circ}$ Cacena's business partners in Antwerp, the Affaitati, could sell I6,000 bales of Azorean woad on the European marketplace in I $543 .{ }^{81}$ It competed vigorously with wheat for available agricultural land, especially on the island of São Miguel, where Captain Donatory Gonçalo Vaz Coutinho lobbied for restricting its cultivation to one-third of the island's cultivated area. ${ }^{82}$ It contributed to the periodic grain shortages of the sixteenth century, although by the end of the century pastel was being replaced in most European markets by cheaper and higher quality dyes from the New World. ${ }^{83}$

\section{“NATURAL” DISASTERS, OR SUPERNATURAL RETRIBUTION?}

The forest-clearing in the Azores was met by ominous portents, which were understood by the human population as protests of Nature. According to the islands' chroniclers, volcanoes erupted and the earth trembled underneath the settlers (abalos de terra). Explosive and effusive eruptions, as well as tectonic earthquakes (sismos), hit São Miguel at seemingly regular intervals thereafter. ${ }^{84}$

What is interesting for our purposes is not the physical causes or even consequences of these tectonic movements, which ecological historians have suggested, even in the case of the largest eruption in human history on the Aegean island of Thera/Santorini c.I628 BCE, do not seem to provide

80. Pierluigi Bragaglia, Lucas e os Cacenas: mercadores e navegadores de Génova na Terceira (sécs. $X V-X V I$ ) (Angra do Heroísmo, 1994). More generally, Francisco Carreiro da Costa, $A$ cultura do pastel nos Açores - subsidios para a sua história (Ponta Delgada, 1946).

81. Lodovico Guicciardini, Belgium Universum, Sen omnium inferioris Germaniae regionum accurata descriptio (Amsterdam, I646), p. IOI, cols I-2. This sales figure is confirmed by independent estimates supplied by the Provedor das Armadas, Pêro Andes do Canto.

82. Faria e Maia, Capitães dos Donatários, p. 262.

83. For an estimate of production on São Miguel, see do Canto, Archivo dos Açores, II, p. I5 5; Hilario Casado Alonso, "El Comercio del Pastel. Datos para una geografía de la industria pañera española en el siglo XVI", Revista de historia económica, 8 (1990), pp. 523-548; and Fritz Lauterbach, Der Kampf des Waides mit dem Indigo (Leipzig, 1905).

84. Primary accounts of these disasters can be found in do Canto, Archivo dos Açores, series "Vulcanismo nos Açores desde a época da descoberta até ao presente", I-VI; J.H. van Linschoten, Navigatio ac Itinerarium Iohannis Hugonis Linscotani in Orientalem sive Lusitanorum Indiam (The Hague, I 599), trans. and reprinted in Boletim do Instituto Histórico da Ilba Terceira, I (1943), pp. I6I-I62; in Padre A. Cordeiro, História Insulana das Ilhas a Portugal sugeitas no Oceano Occidental (Lisbon, I866), I, p. 202; and in Frutuoso, Saudades da Terra, livro IV, pp. $84-87$. 
evidence "for widespread environmental transformation". ${ }^{85}$ Although causing substantial fatalities (around 200 deaths following the Furnas eruption of I630, according to the account of Padre Manuel Gonçalves, a Jesuit from the College of Ponta Delgada), these disasters pale when set next to the 5,000 who perished in the "dreadful earthquake at Lima and Callao" in 1746 , from which only 200 were saved ${ }^{86}$ Rather, I would like to gauge the human response, which here was predominantly one of guilt for the human intrusion on the islands. The human response to this earthquake was much the same as in Lisbon during the famous earthquake of 1755, when the axiom "Whatever Is, Is Right" was adhered to, and which provoked for the first few days following the later Lisbon earthquake contrition and repentance, as if God had punished not only the traditional sins of the ordinary man, but Portugal itself, a land which had been specially chosen by God for His work and which had fallen by the wayside. ${ }^{87}$

We have a good record of the human response to earthquakes in the Azores thanks to a Romance penned in verse form by the chronicler Gaspar Frutuoso, who wrote down the events of I 22 later in the century from hearsay and conversations with elderly people on the islands during his appointment as vicar (vigário) at Ribeira Grande. ${ }^{88}$ Skating over the causes, the tragic event unfolds amidst fine, calm weather, with the dislodging of rocks and earth and landslides, burying the town. The deaths caused provoked lamentations and popular clamour. Frei Afonso de Tolêdo, as a man of the cloth, heard confessions and offered comfort to the survivors. Voices from the earth were heard, but they were illusory,

85. Horden and Purcell, The Corrupting Sea, p. 306; cf. W.F. Jashemski, "Pompeii and Mount Vesuvius, AD 79", in Payson D. Sheets and Donald K. Grayson, Volcanic Activity and Human Ecology (New York, 1979), pp. 587-622.

86. A True and Particular Relation of the Dreadful Earthquake which happen'd at Lima, the Capital of Peru, and the Neighbouring Port of Callao (London, 1750).

87. Cf. Judite Nozes (ed.), The Lisbon Earthquake of 1755: Some British Eye-Witness Accounts (Lisbon, 1987), and Jelle Zeilinga de Boer and Donald Theodore Sanders, "Earthquakes in England: Echoes in Religion and Literature", in idem, Earthquakes in Human History: The FarReaching Effects of Seismic Disruptions (Princeton, NJ, 2005). Jean Delumeau has suggested that the Church in the Counter-Reformation deliberately manipulated typologies of natural disaster so as to replace chronic anxiety over survival with fear of divine retribution for $\sin$. See his $L a$ Peur en Occident (XIVe-XVIIIe siècles): une cité assiégée (Paris, I978).

88. The 360-verse romance forms cap. LXXIII of Livro IV of Gaspar Frutuoso's Saudades da Terra: história das ilhas do Porto-Sancto, Madeira, Desertas e Selvagens, A.R. de Azevedo (ed.) (Funchal, I873), ch. I2. The romance is accompanied by a prose version: "Do grande e furioso tremor ou terramoto da terra que houve na ilha de S. Miguel em tempo de Rui Gonçalves da Camara, quinto Capitão dela e Segundo o nome, con que se subverteu Vila Franca do Campo, a mais nobre e principal das vilas que nele havia"; ibid., cap. LXX. For some literary criticism, see Luís da Silva Ribeiro, O Romance de algumas mágoas do terramoto de Vila Franca em I 52 (Angra do Heroísmo, 195I). Romance verse was a popular way to record relaciones de sucesos, or news, across the iberian world. In his Romancero popular del siglo XVIII (Madrid, 1972) Francisco Aguilar Piñal has collected thousands of such romances published in Andalusia. 


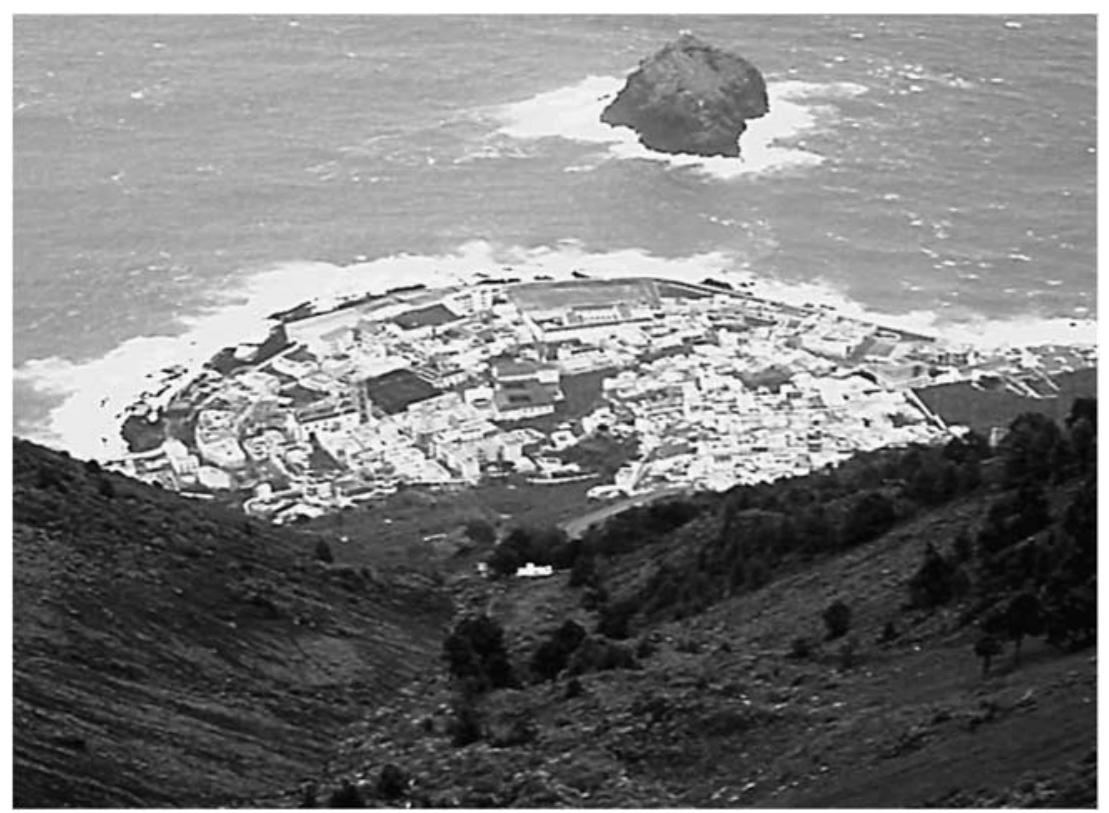

Figure 5. Photograph of Garachico, rebuilt on the lava delta formed by the eruption of 1706 . Terra Publishing, London. Used with permission.

for what was recovered were only corpses and goods. Further otherworldly signals were heard: in the sky, for instance, and new tremors followed. In I 59I, inhabitants aware of these portents, quickly took to the fields and abandoned their houses, which were filled with "grief-filled lament" (lastimoso pranto). Meanwhile, rather than a tsunami or fires which burned for weeks, as occurred in Lisbon in 1755, in the Azores a plague attack quickly followed, lasting eight years. Thus, as is common in such circumstances, it was the consequences of the earthquake rather than the earthquake itself which caused the greater environmental impact in the case of São Miguel. A substantial population exodus to Brazil followed this sorry chapter in the island's history.

The Canary Islands, and here specifically Tenerife and Gran Canaria, also bore the brunt of repeated volcanic eruptions, an estimated twelve since the sixteenth century. ${ }^{89}$ Here again, reports tend to downplay the immediate damage, though in the case of an eruption on 5 May i706 on Tenerife an entire town (Garachico) subsequently disappeared under the molten basalt, which then spread in a fuming lobe into the sea (see Figure 5).

89. See Table I "Volcanismo reciente en el Archipielago Canario", in J. Fuster et al., Geología y Volcanologia de las Islas Canarias (Madrid, 1968) (volumes on Tenerife and Gran Canaria). 
Although nobody was killed on this occasion, as the community had time to flee with their possessions to the neighbouring town of Icod, the entire town had to be rebuilt, the plan retraced over the surface of the new lava flows rather than being recommenced elsewhere, as was the case with a number of towns relocated after flooding in the Paraná valley, such as Corrientes (1598) and Santiago del Estero (1630). ${ }^{90}$ While accounts of this natural disaster focus less on humanity's responsibility for this calamity, religiosos nevertheless had an important role to play in sustaining morale and God was invoked for succour rather than attributing blame. In many ways, the inhabitants of the Canaries took events as they unfolded in their stride, as if it were part of the original scheme of colonization: their predecessors, the Guanches, had long savoured a healthy respect for the power of the volcano, Teide, towering over them, and which they had called Echeide, the inferno. ${ }^{9 \mathrm{I}}$

To conclude, while earthquakes and the ensuing plague outbreak in the case of São Miguel have been accorded by some historians the responsibility for an early end to the Azorean sugar industry, ${ }^{92}$ it is equally interesting to assess the impact on the human inhabitants, who in their eyes bore the responsibility for the natural cataclysm, and which they explained in terms of their forest clearances and disturbances of the natural equilibrium.

\section{THE POPULATION DYNAMICS OF MID-ATLANTIC COLONIZATION}

In all of this, the strikingly polarized fates of the different islands in the mid-Atlantic need to be emphasized. We can demonstrate this point best in terms of populations. Initially, there was nothing to distinguish the demographic strategies from one island to the next. Free labour in Madeira - principally the emigration during the I 420 s of farmers from lands belonging to Prince Henry or to the Order of Christ, the majority coming from the Algarve - was supplemented by the importation of slave labour from Africa, estimated at around 3,000 souls in $1522 .{ }^{93}$ In the Azores, at first the Crown planned to transport convicts (degredados) to populate the island of São Miguel in I453, a policy which was put into

90. María del Rosario Prieto, "The Paraná River Floods during the Spanish Colonial Period: Impact and Responses", in C. Mauch and C. Pfister (eds), Natural Disasters, Cultural Responses: Case Studies Toward a Global Environmental History (Lanham, MD, 2009), p. 296. 91. Carmen Romero Ruiz, Las Manifestaciones volcánicas históricas del Archipiélago Canario, 2 vols (Sta Cruz de Tenerife, I991); cf. J.C. Carracedo et al., "The I677 Eruption of La Palma, Canary Islands”, Estudios Geológicos, 52 (1996), pp. I03-1 I4.

92. Andrzej Dziubiński, "La Fabrication et le Commerce du Sucre au Maroc aux I6 et i7 siècles", Acta Poloniae Historica, 54 (1987), pp. 5-37.

93. Mauro, Le Portugal et l'Atlantique, p. i so; see also António H. de Oliveira Marques, História de Portugal (Lisbon, I973), I, p. 2 I 8. 
force the following year. ${ }^{94}$ Numbers were supplemented by blacks and Moorish slaves. ${ }^{95}$ It was their combined labour that cleared the forests on islands such as São Miguel prior to the earthquake.

But overpopulation (superpovoamento), rather than underpopulation, rapidly became the chronic problem of these islands. On some, such as Madeira and São Miguel, the population outstripped even those islands' very rich agricultural resources, and emigrants were found from the Micaelenses by the Governor General and founder of the Captaincy of Bahía, Tomé de Sousa; they moved on to Brazil in return for food and transport aboard as well as "lands for cultivation and to exploit freely other than the payment of the tenth to God" (terras para plantarem e aproveitarem livremente sem delas pagarem mais do que a dizimo a Deus). ${ }^{96}$ In the seventeenth and eighteenth centuries, the surplus population of Madeira and the Azores found employment in the King of Portugal's armies and navies and were an important element in the settlement and colonization of Brazil, particularly the southern province of Santa Catalina. ${ }^{97}$

This situation needs to be contrasted with that, say, in the poorly watered Cape Verdes. Here there has never been enough arable land to sustain more than a few people, although rather than persisting with the traditional cereals (rye, barley, wheat) instead experiments were made with milho miúdo, or pearl millet, which was grown on the African mainland opposite the islands, to moderate success. ${ }^{98}$ As the Portuguese historical geographer Orlando Ribeiro succinctly put it: "In such a land so unfavourable to agriculture, the type of colonization which was characteristic of the Azores and Madeira was not possible." 99

The imported European human population suffered terribly from malaria, diagnosed by European physicians at the time as "remittent" or "intermittent" fevers, that burgeoned during the rainy season (tempo das águas)

94. Da Silva Marques, Descobrimentos Portugueses, I, p. 517, II, p. 344.

95. Gaspar Frutuoso, Saudades da Terra (Ponta Delgada, I998), livro IV, p. Io.

96. Do Canto, Archivo dos Açores, XII, p. 4I4 (Carta de El-Rei D. João III, i September I 550 ).

97. Maria da Conçeição Vilhena, "Viagens no século XVIII. Dos Açores ao Brasil", Studia, 5 I (1992), pp. 5-I 5; Raquel Soeiro de Brito, "Aspectos da emigração na ilha de S. Miguel”, Estudos de História de Portugal: homenagem a A.H. de Oliveira Marques, II (Lisbon, 1983), pp. 533-546; José Damião Rodrigues, "Das ilhas ao Atlântico Sul. A Politica Ultramarina e a emigração Açoriana para o Brasil no reinado de D. João V", Anais de História de Além-Mar, 8 (2007), pp. 57-67.

98. This was almost certainly Pennisetum glaucum (L.) R. Br. and not Panicum miliaceum Lin., a milho minido grown in northern Portugal. For a discussion of the problems associated with the early modern usage of the Portuguese term milho see Paul E.H. Hair, "Milho, Meixoeira and Other Foodstuffs of the Sofala Garrison, I 505-1 525", Cabiers d'Études Africaines, 17:66-67 (1977), pp. 353-363.

99. Orlando Ribeiro, Aspectos e Problemas da Expansão Portuguesa (Lisbon, 1962), pp. $156-158$. 


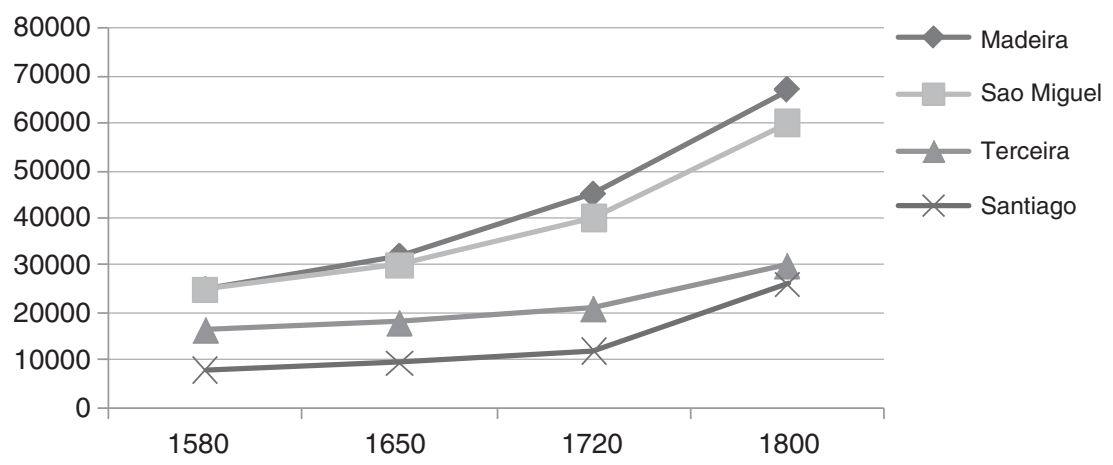

Figure 6. Island population growth, I 580-1800. [Madeira, São Miguel, Terceira, Santiago] Statistics taken from Duncan, Atlantic Islands, appendix II.

between July and October rendering the islands a "white man's grave" and which seriously threatened colonization. The Florentine merchant Francesco Carletti, who visited Santiago in I 593, wrote that Europeans were never healthy on that island and that the few Portuguese he saw there were weak and pallid, seeming more dead than alive. ${ }^{100}$ Six Cape Verdean governors died before the completion of their triennial terms of office during the seventeenth century, and three bishops also died after brief terms of service. Of seven Jesuits who arrived in 1604 and I606, four died within a few weeks and the mission had to be closed. ${ }^{\text {IoI }}$ Consequently, generous tax concessions and other regálias needed to be offered to induce colonists to move there. ${ }^{\mathrm{I}}{ }^{2}$ This policy was supplemented by degredo, the judicial commutation of lengthy prison sentences to banishment and exile, which proved particularly successful as a method for peopling the islands of S. Tomé and Principe to the south. ${ }^{103}$

ı००. Francesco Carletti, Ragionamenti del mio viaggio intorno al mondo (Milan, I94I), p. 7. ıог. Cabo Verde, Guiné, S. Thomé e Príncipe: curso de extensão universitaria - ano lectivo 1965-66 (Lisbon, 1965), pp. 515-525. For the tribulations of the Jesuit mission, see Nuno da Silva Gonçalves, SJ, Os Jesuitas e a missão de Cabo Verde (I604-I642) (Lisbon, I996).

I02. "A ylha de sam tome priuillegio aos moradores della pera poderem resgatar e trautar todallas mercadorías e cousas nadas e criadas na dita ylha, na terra firme dello rio Real ilha de fernam de poò Atee toda a terra de mani comgo e outras liverdades qui feitas na dita carta"; 26 March i 500 , Arquivos Nacionais da Torre do Tombo, Lisbon, Livro das Ilhas, f. 8 I.

I03. The number of convicts exiled in the Cape Verdes was actually low: only i 4 individuals between I466 and I5 I3, if we go by the documents published in Luís de Albuquerque (ed.), História Geral de Cabo Verde: Corpo Documental, 2 vols (Lisbon, I988-1990). A substantial number of Jewish children who ended up in Portugal after the official Spanish expulsion order of 1492 were sent to S. Tomé with Álvaro da Caminha, appointed second Captain-General over the islands in the same year. See Chronica del Rey D. João II, M. Lopes de Almeida (ed.) (Porto, 1977), ch. 68. 
The European arrival in the Canary Islands, however, heralded the fullscale population collapse of its light-skinned native Guanches peoples, whom both genetic (ABO allele frequencies) and linguistic evidence (base-Io counting systems, Libyco-Berber and Punic inscriptions in rock carvings) relate to the pre-Islamic Berbers of North Africa, and who had little more than Neolithic technology and reared goats and pigs. ${ }^{104}$ Archaeological evidence suggests they possessed no nautical skills and had been out of touch with the African mainland since migrating there at

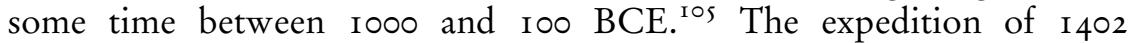
undertaken by Jean de Béthencourt and Gadifer de la Salle in the name of the King of Castile landed in Lanzarote, built a fortress, captured the ruler of one of the smaller outlying islands, and forced a military surrender, followed by Christian baptism for the subjugated population. Thereafter, it took the colonists over ninety years to conquer all seven islands despite the Portuguese Prince Henry's repeated expeditions to make conquests and plant settlements - for although armed only with javelins and rocks, the Guanches' knowledge of the mountainous terrain and determination to hang on to their land and way of life made them formidable opponents (see Figure 7).

Eventually, plague achieved what horses, cannons, and armour and muskets could not; on Christmas Day I 495 the last Guanches surrendered in Tenerife. Remaining insurgents were hunted down from the hills, their traditional dress was outlawed and they were sold as slaves and put to work on the new sugar plantations, just as their brethren had been enslaved over the previous Ioo years. Others were taken to Valencia, Andalusia, the Algarve, and Madeira. ${ }^{106}$

The extinction of the Guanches as a race from around this time tends in historical scholarship to be overshadowed by the debate over Easter Island and the fate of its population, doomed by deforestation and overfishing, perhaps spurred on by the immense, eerie statues (moai) left behind as testimony to their erstwhile presence. ${ }^{107}$ In truth, the two are not commensurable phenomena, for the Guanches were a victim of genocide from without and the Easter Islanders of extermination from within. But accusations of genocide, so easily presented from standard

I04. N. Maca-Meyer et al., "Ancient mtDNA Analysis and the Origin of the Guanches", European Journal of Human Genetics, I 2:2 (2004), pp. I 5-162; J. Bynon, "The Contribution of Linguistics to History in the Field of Berber Studies", in David Dalby (ed.), Language and History in Africa (New York, 1970), pp. 64-77. The Guanches in fact comprised a number of linguistically and perhaps ethnically quite distinct peoples.

105. Felipe Fernández-Armesto, The Canary Islands After the Conquest (Oxford, 1982), pp. 5-I 2.

I06. Alberto Artur Sarmento, Os escravos na Madeira (Funchal, I938).

107. Jared Diamond, Collapse: How Societies Choose to Fail or Succeed (New York, 2005). 


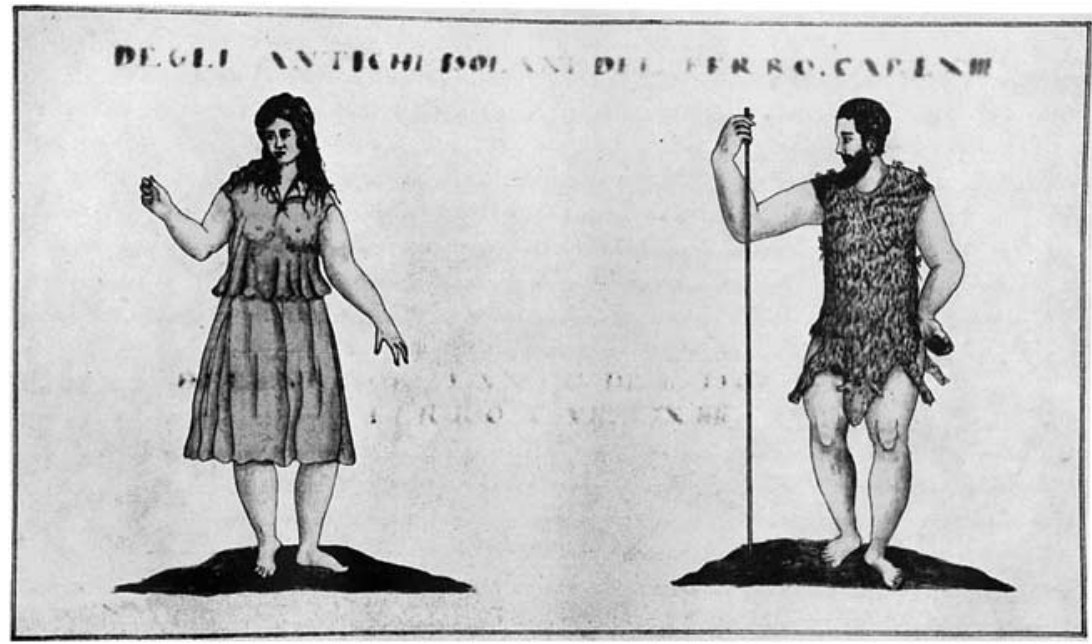

Figure 7. A rare illustration of Canary Island Guanches from the island of El Hierro, c. I 590. Leonardo Torriani, "Descrittione et historia del regno de l'isole Canarie". University Library of Coimbra, Portugal. Used with permission.

historical narratives of the conquest of the Canaries, run into obstacles when confronted with the findings of modern science, which has shown how aboriginal Guanche mitochondrial DNA (collected from Canarian archaeological sites) has been passed on to today's Canarians in considerable proportions.

According to the recent findings of Nicole Maca-Meyer and her research partners, "despite the continuous changes suffered by the population (Spanish colonization, slave trade), aboriginal mtDNA (direct maternal) lineages constitute a considerable proportion (42-73 per cent) of the Canarian gene pool". She goes on: "since the end of the I6th century, at least two-thirds of the Canarian population had an indigenous substrate". ${ }^{108}$ Y-DNA, or Y-chromosomal (direct paternal) lineages, were not analysed in this study. However, the researchers cite an earlier study giving the aboriginal Y-DNA contribution at 6 per cent, ${ }^{\text {I09 }}$ although these results have been critiqued as possibly flawed. Regardless, Maca-Meyer et al. state that historical evidence does support the explanation of "strong sexual asymmetry [...] as a result of a strong bias favouring matings between European males and aboriginal females, and to the important aboriginal male mortality during the Conquest". ${ }^{\text {Io }}$ So, there are two sides

I08. Identified as mtDNA haplogroup U subclade U6br.

I09. C. Flores et al., "A Predominant European Ancestry of Paternal Lineages from Canary Islanders", Annals of Human Genetics, 67 (2003), pp. I38-1 52.

I Iо. Maca-Meyer, "Ancient mtDNA Analysis and the Origin of the Guanches", p. I55. 
to the coin: while the European conquest of the Canaries saw the extermination of Guanche males, females were selected as mating partners and, through them, Guanche genes were passed on.

\section{CONCLUSIONS}

Ecocide is, more than anything, a call today to raise world attention on environmental issues and as such is a political programme, rather than a historically verifiable state of affairs. Historians of the mid-Atlantic islands would do better to heed the notion of economic cycles, different productive phases in the islands' history, and bear witness to the social tensions arising from competing notions of land use: between cereal cultures and the sugar industry, between silviculture and agriculture, between cash-cropping exporters and those who sought to attract population, between mobile, pastoralist populations (initially the Guanches, later the poorer elements of society) and sedentary ones (both townbuilders and fazendistas keen to cadastralize land and establish clear boundaries of possession).

The islands may have lost a large part of their forest cover, to the point that trees like the Madeiran til are now registered on the IUCN Red List of Endangered Species, and even their original human population, but rather than becoming redundant wastelands, instead became beacons for international trade and expanding, successful agricultures, whether sugar, cereals, or wine. Rather than preach catastrophism, which is generally unconvincing, ${ }^{\text {II }}$ we would do better to see the relationship between human life and nature as interactive and embedded within a kaleidoscopic environment in which little or nothing is permanent, and in which there are winners as well as losers. 